\title{
The Study of Dock Performance of Citranusa Port at Kabil, Batam
}

\author{
Slamet Hargono ${ }^{1}$, Sugiono Soetomo ${ }^{2}$, Joesron Alie Syahbana ${ }^{3}$ \\ \{slamet.hargono@ft.undip.ac.id ${ }^{1}$, sugiono.soetomo@pwk.undip.ac.id ${ }^{2}$, \\ joesron.syahbana@pwk.undip.ac.id $\left.{ }^{3}\right\}$
}

Civil Engineering Department, Engineering Faculty, Diponegoro University, Semarang-50275, Central Java, Indonesia ${ }^{1}$, Urban and Regional Development, Faculty of Engineering, Diponegoro University, Semarang-50275, Central Java, Indonesia ${ }^{23}$

\begin{abstract}
The researcher analyzed the data of ship traffic and loading and unloading of goods in 2010 until 2016, to get the value of berth occupancy ratio (BOR), berth throughput (BTP). The result of data analysis during the study found that the lowest monthly value of BOR is $1.60 \%$ and the highest is $67.40 \%$, where the result still meets the standard guideline of BOR. For goods passing dock 1,763,07 ton / meter / month and dock capacity $310.299,54$ ton / month. Based on the regression analysis of the ship arrival flow and the flow of goods on the dock shows a decrease, it can be concluded that the dock facility is sufficient to be able to serve the flow of goods and the arrival of existing ships.
\end{abstract}

Keywords: cargo ship, BOR, BTP, equipment capacity, regression method.

\section{Introduction}

Port is a supporting infrastructure of sea transportation that serves as a place for stops and transportation support for Indonesia[1]. Meanwhile, the transport function itself is to transport passengers or goods from one place to another with a specific purpose. Batam is an highly potential area to be developed due to the strategic geographical position. It is also meet the industrial and economic interests of the Government of Indonesia. The central government of Indonesia established Batam as a free trade zone and a free port.

Citranusa Kabil Port is a public port located in Kabil Industrial Zone in Batu Besar Village, Nongsa District, Batam City, Riau Islands Province. Citranusa Kabil Port as a public port that operates on cargo loading and unloading activities. Citranusa Kabil supporting activities in the Kabil Industrial Estate. The facilities owned by the port of Citranusa Kabil are 5 docks, office space, warehouse and open storage. This is also supported by the capability and resources of the port to support all operational requirements such as stocking and staging points for offshore drilling so that it serves as a logistics and operational basis for supporting companies in oil and gas drilling activities in the Kabil industrial area. This evaluation was conducted to assess the level of dock performance for the development of Kabil industrial area especially in Batam area. Considering the Port of Citranusa Kabil is a private port managed by third parties PT. Sarana Citranusa Kabil. 
The most recent such tools evaluate seaport performance and, regardless of the methods used, are founded on a set of indicators that allow full monitoring of sets of characteristics, activities and/or processes that enable managers to achieve excellent performance[2].

\section{Research Purposes}

The purpose of this study is to know the amount level of ships, the flow of goods, Berth Occupancy Ratio (BOR) and Berth Throughput (BTP) in the service of loading and unloading of goods at the Port of Citranusa Kabil.

\section{Literature Review}

Multicriteria and Multvariate Analysis for Port Performance Evaluation [3] proposed a multicriteria decision aid (MCDA) Performance Evaluation model that is realist and uses the operational indicators suggested by the Brazilian National Agency of Maritime Transport.

Shipping capacity is one of the researched topics in seaport management[4].

Efficiency of Middle Eastern and East African Seaports: Application of DEA Using Window Analysis [5] studied the evolution of productivity in 22 seaports in East Africa and the Middle East, using DEA to evaluate "normal efficiency" and "super efficiency".

The dock performance indicators are used to measure the extent to which dock facilities and supporting facilities are utilized intensively. Indicators of dock performance assessment include types of goods, ship size, work productivity of loading / unloading, number of alleys, number of working hours and work shifts and length of moorings.

Measurement of port service performance is one of the methods used to determine the overall port utilization of ship service, loading and unloading goods and utility dock. The measured vessel service is berthing time, berth working time, not operation time, effective time, and idle time. For port loading and unloading service the port feasibility is measured from loading / unloading speed at port (tonnes per ship hour in port) and loading and unloading speed at mooring (tonnes per ship hour in berth).

Meanwhile, the dock utility is indicated by the occupancy ratio (BOR) or dock usage rate, which is the comparison between the total usage time of each pier available and the amount of time available for one period (month / year) expressed in percentages. Berth throughput (BTP) is the amount of unloaded goods at each mooring and expressed in tonnes $/ \mathrm{m} / \mathrm{month}$. Dock capacity or dock usage rate is the amount of goods (tonnes) in one period (month / year) that can be served by the dock and expressed in tonnes / month.

\section{Research Methodology}

Research methodology is a process or a scientific way used to obtain data in order to obtain research objectives. In the implementation of this research carried out steps to achieve research objectives in which by using research methods are made.

This study uses the Knowledge Development Process [6] to investigate published research with a focus on a given particularity of the research topic in question. 
The procedure reads the title of the articles and selects those likely to align with the research topic. This gives the researchers the opportunity to develop their understanding on the variety of ways the research topic is dealt with in academia [7]. A published research from various fields of study has used the Knowledge Development Process to uncover gaps in the literature to target further research[8].

\section{Data Requirements}

This study was designed using descriptive methods with quantitative analysis. Then after determining what data will be collected, from which data can be obtained and by what method the researcher will collect data needed in data analysis. Data collection techniques conducted in this study using two methods, namely:

1) Primary Data Collection Primary data is a type of data that researchers get directly from the research location. Primary data collection was conducted at Citranusa Kabil Port, Batam Island. Some of the primary data needs done by researchers as follows:

a) The survey of the location of the Citranusa Kabil Port was carried out to determine the port position and environmental conditions around the port.

b) Field observation, aimed to get the required data.

c) Resource interviews, conducted with resource persons working in the Port of Citranusa Kabil to determine the internal and external conditions that exist in the port.

d) Field documentation, as an illustration to know the loading and unloading activities and conditions at the dock.

2) Secondary Data Collection

Secondary data is data obtained from existing sources. Secondary data is generally in the form of evidence, records, or historical reports that have been arranged in the archive, including data loading / unloading monthly goods, monthly vessel data and ship characteristics, dock data, the open storage, dock layout and data loading / unloading tool usually obtained of the company archives.

\section{Result and Discussion}

\subsection{Analysis of Port of Citranusa Kabil Port}

Regression method with product moment correlation is used to predict the predicted increase in ship flow and the flow of goods at the Citranusa Kabil Port dock in the coming years. To limit the recommended correlation coefficient according to Statistic for Research as Table 1. [8] are as follows: 
Table 1. Level of Correlation - Coefficient Relation.

\begin{tabular}{ll}
\hline Coefficient Interval & Correlation Level \\
\hline $0,00-0,199$ & Very low \\
$0,20-0,399$ & Low \\
$0,40-0,599$ & Medium \\
$0,60-0,799$ & Strong \\
$0,80-1,000$ & Very Strong \\
\hline
\end{tabular}

\subsection{Analysis of Number of Ship Pier}

The number of ship flows in 2010-2016 experienced a fluctuating condition, in which in 2016 experienced the largest decline in goods, reaching $81.58 \%$, the following is the data on the goods at the Citranusa Kabil Port Pier as follows:

Table 2. Data of Citranusa Kabil Harbor Dock Port of Kabil in 2010-2016

\begin{tabular}{lll}
\hline Year & Number of Ship (units) & Development of Ship (\%) \\
\hline 2010 & 154 & - \\
2011 & 217 & 29.03 \\
2012 & 165 & 31.52 \\
2013 & 244 & 32.38 \\
2014 & 250 & 2.40 \\
2015 & 138 & 81.16 \\
2016 & 76 & 81.58 \\
\hline
\end{tabular}

\subsection{Analysis of Amount of Goods Pier}

The amount of goods flow in 2010-2016 experienced a fluctuating condition, where in 2016 experienced the largest decline in goods which reached $151.60 \%$, the following is the data of the goods at the Citranusa Kabil Port Pier as follows:

Table 3. Data of Goods Port Current Port of Citrususa Kabil in 2010-2016

\begin{tabular}{cll}
\hline Year & The Amount of Goods (tonnes) & Development of Goods $(\%)$ \\
\hline 2010 & 364,237 & - \\
2011 & 126,565 & $-187,78$ \\
2012 & 106,209 & $-19,17$ \\
2013 & 177,589 & 40,19 \\
2014 & 112,350 & $-58,07$ \\
2015 & 159,864 & 29,72 \\
2016 & 63,540 & $-151,60$ \\
\hline
\end{tabular}

The calculation of ship flow using Ms.Excel assistance with linear regression analysis approach where $\mathrm{x}$ is year and $\mathrm{y}$ is the flow of goods. Here is a graph of goods of the Port of Citranusa Kabil:: 


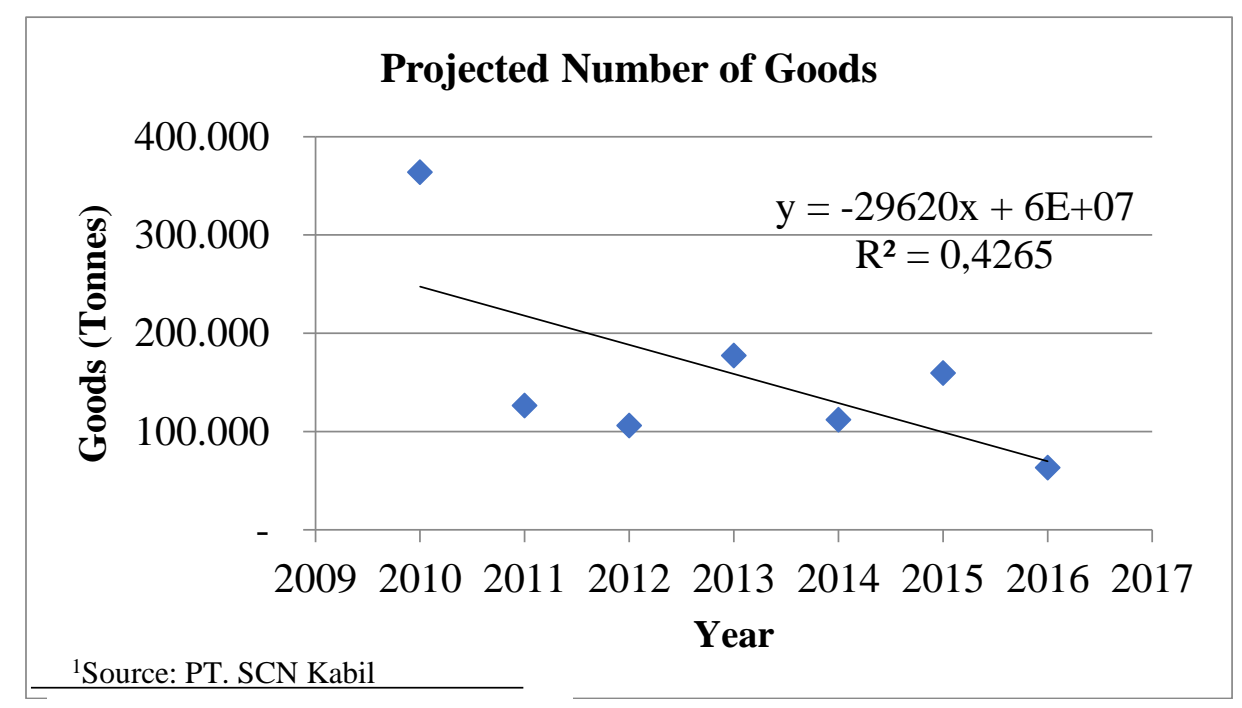

Fig. 1. Calculation of Goods Flow Data (2010-2016).

Based on the above graph and the emerging regression equation, the berth current equation is obtained as follows:

$\mathrm{y}=-29.620 \mathrm{x}+6 \mathrm{E}+07$

with $r=\sqrt{r^{2}}=\sqrt{0,4265}=0,653$

notes :

$\mathrm{y}$ : the flow of goods (tons)

$\mathrm{x}$ : year-

From the linear regression graph above, the correlation coefficient value $r=0.653$ shows that the variable $\mathrm{x}$ years and variable $\mathrm{y}$ flow of goods has a strong relationship. So the equation is a positive relation and can be generalized to the population in which the sample is taken or the regression result data can reflect the state of the goods to come. So it can be concluded that there is a decrease in the flow of goods coming from 2010 to 2016.

\subsection{Analysis of Berth Occupancy Ratio (BOR) Dock}

BOR is the rate of use of the dock used to determine the utility of each dock at the port. In the analysis of BOR values are used general BOR equation, as follows:

$$
\mathrm{BOR}=\frac{\text { Vs } \times \mathrm{St}}{\text { Effective Time } \times \mathrm{n}}
$$

The recommended BOR limit according to UNCTAD (United Nations Conference on Trade and Development) to dock the recommended BOR value is $50 \%$, because the available moorings are 2 moorings. And the value of BOR based on the Decree of the Director General of Sea Transportation Number: UM.002 / 38/18 / DJPL-11 for Port of Sri Payung Batu Anam, Tanjung Pinang. This is because according to the 2015 Sea Transportation Statistics book, the Port of Sri Payung Batu Anam is a public goods port and port location is still in the Riau 
Islands region. So the value of BOR in the Port of Sri Payung Batu Anam 70\% can be used as a standard value of BOR for Citranusa Port Kabil.

The following is the monthly BOR realization value at the Citranusa Kabil Port pier in 2010 to 2016, where the results are compared with the UNCTAD standard and the Decree of the Director General of Sea Transportation:

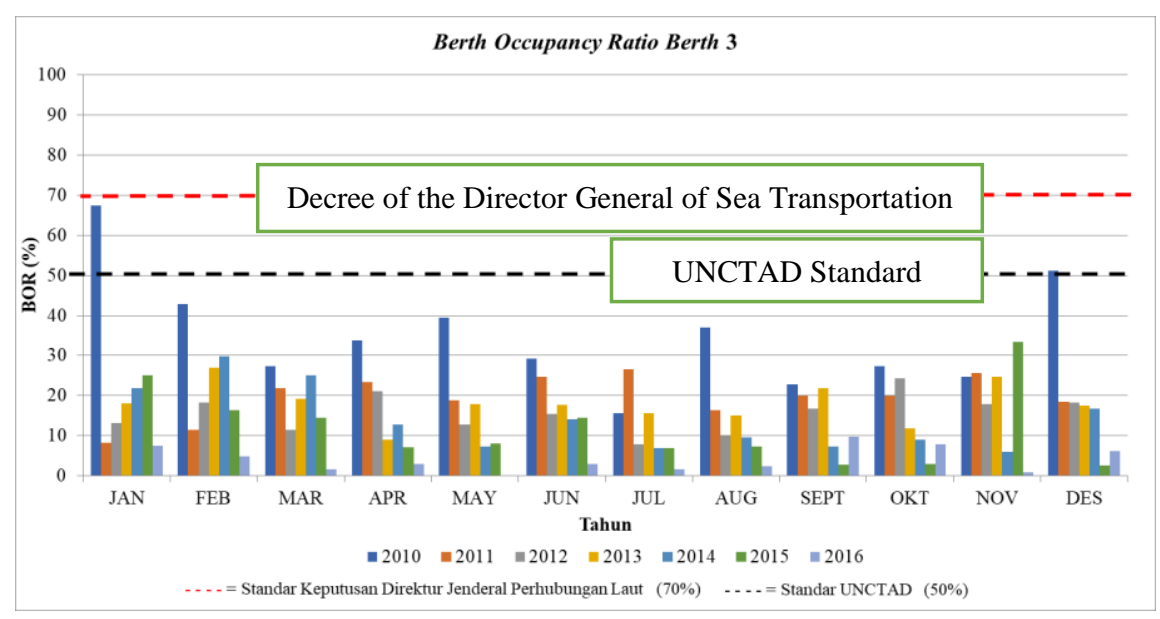

Fig. 2. Berth Occupancy Ratio 2010-2016.

Based on the data on the number of cargo ship visits in Table 2, the number of berth is 2 moorings (n) and the effective time at the dock (number of days each month (days)) so that the largest BOR value on the dock is $67.40 \%$. This BOR value is greater than the maximum limit of UNCTAD of 50\%, where according to UNCTAD the dock conditions in January 2010 have served the flow of dense vessels. However, overall the BOR value still meets the standard value of the Decision of the Director General of Sea Transportation as $70 \%$, where the condition of the dock has not experienced the current density of the ship. In addition, in March 2016 the BOR value at the dock showed a very small number of $1.60 \%$ because based on the small monthly ship visits compared to the number of days available (effective time) every month is greater than the mooring time (berthing time). The results of multiple linear regression analysis show that the volume of loading and unloading activities and the development of ship arrival patterns have a direct and significant positive effect on port operational performance.

Factors that significantly influence the increase in BOR include Service time (St) and the number of ship visits. The higher the value of Service time means that the vessels that dock at the pier are longer, where the factors that correlate with the increase in service time is the capacity of the ship which is the ratio of the total cargo of the ship to the number of ships. This affects the higher performance of BOR. In addition, the increasing number of boat visits will increase the BOR value.

\subsection{Analysis of Berth Throughput Dock}

According to Sea Port [9] Berth Throughtput (BTP) is the quantity of goods dismantled and loaded in a period at the dock per meter length of moorings. The greater the value of BTP then the service amount of goods coming into the dock will be greater. Here is the formula used: 


$$
\mathrm{BTP}=\frac{\text { H BOR J G P }}{L_{1}}
$$

For the throughput that has taken place in Citranusa Kabil Port, it is calculated from 2010 to 2016. Based on the loading and unloading volume data of goods in Table 3, the largest BTP value is 1,760 tonnes / $\mathrm{m} /$ month and the pier capacity is 310,300 tonnes / month in September 2015. The results of the analysis found that the installed capacity of the dock $(\mathrm{Kd})$ was still greater than the power then the goods that had been running on the dock.

BTP values vary every year. The higher the flow of incoming goods, the higher the dock capacity. However, the optimum capacity can be estimated with the average value of the occupancy ratio (BOR) to the maximum required by UNCTAD and the maximum value of port tool productivity. If it is not enabled by the second requirement then capacity will continue to increase if throughput (BTP) increases.

\section{Conclusion}

Based on the analysis of ship flow and flow of goods it is found that there is a decrease of ship flow and the flow of goods from 2010 to 2016. The performance level of Citranusa Kabil Port has the greatest BOR (Berth Occupancy Ratio) value of $67.40 \%$ which has exceeded the BOR standard issued by UNCTAD 50\%. BOR value as a whole still meets the BOR value standard Decree of the Director General of Sea Communications that is $70 \%$. For data throughput from the results of data analysis obtained 1,760 tonnes / $\mathrm{m} /$ month and capacity of 310,300 tonnes / month, so that the capacity of the dock $(\mathrm{Kd})$ is still greater than the number of goods (BTP), which has been running in the dock.

\section{References}

[1] B. Triatmodjo, Sea Port. Yogyakarta: Beta Offset, 2010.

[2] A. D. V. M. R.-F. A. G. F. S. R. E. L. Ensslin, "BPM governance: A literature analysis of performance evaluation," Bus. Process Manag. J, vol. 23, pp. 71-86, 2017.

[3] A. R. C. S. H. S. Madeira, A.G., M.M. Cardoso, M.C.N. Belderrain, "Multicriteria and multivariate analysis for port performance evaluation," Int. J. Prod. Econ, vol. 140, pp. 450-456, 2012.

[4] Y. J. W. and M. Goh, "Container port efficiency in emerging and more advanced markets," Transp. Res. Part E, vol. 46, pp. 1030-1042, 2010.

[5] A. S. M. T. K. P. B. Al-Eraqi, "Efficiency of Middle Eastern and East African seaports: application of DEA using window analysis," Eur. J. Sci. Res., vol. 23, no. 4, pp. 597-612, 2008.

[6] and K. S. L. Ensslin, V. Dezem, A. Dutra, S. R. Ensslin, "Seaport-performance tools: an analysis of the international literature," Marit. Econ. Logist., pp. 1-16, 2017.

[7] S. R. E. L. E. Dutra, A., V.M. Ripoll-Feliu, A.G. Fillol, "The construction of knowledge from the scientific literature about the theme seaport performance evaluation," Int. J. Prod. Perform. Manag., vol. 64, pp. 243-269, 2015.

[8] Sugiyono, Statistics for Research. Bandung: CV Alfabeta, 2007. 